Original Research Paper

\title{
Keluhan Musculoskeletal Pada Mahasiswa Selama Pandemi Covid-19: Literatur Review
}

\author{
Madschen Sia Mei OI Siska Selvija Tambun ${ }^{1}$ \\ ${ }^{1}$ Department of Industrial, Faculty of Engineering, Sari Mulia University. Banjarmasin, \\ Indonesia.
}

\section{Article History \\ Received: \\ 31.10 .2021}

Revised:

23.11.2021

Accepted:

12.12.2021

*Corresponding Author: Madschen Sia Mei Ol Siska Selvija Tambun

Email:

marunehutabarat10041979@ gmail.com

This is an open access article, licensed under: $\mathrm{CC}-\mathrm{BY}$-SA

\begin{abstract}
Abstrak: Pandemi Covid-19 telah menjadi perhatian di seluruh dunia. Kebijakan dalam rangka pencegahan penyebaran virus seperti pembelajaran online juga diberlakukan pada mahasiswa. Mahasiswa yang mengikuti pembelajaran online mayoritas mengalami keluhan musculoskeletal pada bagian tubuh seperti leher, bahu, punggung dan pinggang. Metode penelitian ini adalah literatur review dengan menghasilkan 14 artikel penelitian. Keluhan musculoskeletal apabila tidak ditindaklanjuti maka akan berdampak jangka panjang seperti gangguan tidur dan kecacatan.
\end{abstract}

Kata Kunci: Covid-19, Gangguan Muskuoskeletal, Pelajar, Pembelajaran Online.

\section{Musculoskeletal Disorders in Students During Covid-19 Pandemic:} Literature Review

Abstract: COVID-19 pandemic has become an international concern. Policies to prevent the spread of disease, such as learning from home, are applied to university students. The majority of students who take online learning experience musculoskeletal complaints in body parts such as the neck, shoulders, back and waist. This research method is literature review by producing 14 research articles. Musculoskeletal complaints if not followed up will have long-term impacts such as sleep disturbances and disability.

Keywords: Covid-19, Muscuoskeletal Disorders, Online Learning, Student. 


\section{Pendahuluan}

Pada Desember 2019, penyebaran Coronavirus yang disebabkan oleh SARS Coronavirus 2 yang bermula dari Kota Wuhan dan sudah diumumkan secara resmi oleh Badan Kesehatan Dunia (WHO) sebagai wabah global pada 11 Maret 2020 [1]. Sampai 21 April 2021, lebih dari 134 juta orang terinfeksi Virus Corona, dan 2,9 juta meninggal akibat terpapar virus ini [2]. Berdasarkan data dari Satgas Covid19 sampai dengan Oktober 2021, korban yang meninggal sudah mencapai lebih dari 143.000 jiwa [3]. Pandemi ini banyak menimbulkan kerugian yang tidak sedikit dan hampir di semua sektor. Salah satunya adalah sektor pendidikan. Sektor pendidikan mulai dari Sekolah Dasar (SD) sampai dengan Perguruan Tinggi (PT) memberlakukan proses pembelajaran secara online untuk mengurangi aktivitas kerumunan massa [4]. Pembelajaran secara online memberi dampak terhadap aktivitas fisik pada mahasiswa. Kurangnya aktivitas fisik dan berada pada postur tubuh yang sama di depan perangkat elektronik seperti laptop, smartphone, dan tablet mempengaruhi kenyamanan sistem musculoskeletal [5]. Duduk statis dan terus menerus di depan perangkat elektronik, postur janggal dari ekstremitas atas termasuk punggung atas termasuk punggung atas dan leher adalah faktor risiko meningkatnya keluhan musculoskeletal. Studi di Eropa yang berhubungan dengan keluhan musculoskeletal di tempat kerja berkontribusi besar terhadap sebagian besar masalah kesehatan. Satu dari empat pekerja di Eropa mengalami keluhan di bagian ekstremitas atas, bahu dan leher [6]. Beberapa penelitian terdahulu menunjukkan bahwa penggunaan komputer dengan durasi lebih empat jam sehari berisiko meningkatkan keluhan musculoskeletal [5], seperti pada leher, kekakuan bahu, tenosynovitis pada lengan bawah, sindrom terowongan karpal dan Quervain syndrome [7]. Berdasarkan penjelasan diatas, maka tujuan penelitian ini adalah untuk menganalisa keluhan musculoskeletal pada mahasiswa.

\section{Metode Penelitian}

Penelitian ini menggunakan metode literatur review dimana merupakan sebuah metode analisis artikel melalui telaah literatur yang dipilih dari beberapa sumber sehingga menjadi sebuah pembahasan yang baru. Sumber referensi yang digunakan didapatkan melalui database penyedia jurnal google scholar, Pubmed, Scientific Research dan Taylor \& Francis Online yang dilakukan selama Bulan Oktober 2021 dengan kata kunci keluhan MSDs, Covid-19, pembelajaran online, pembelajaran daring, dan mahasiswa. Berdasarkan hasil pencarian yang sesuai dengan kata kunci didapatkan sebanyak 535 artikel. Dari hasil seleksi, diperoleh 14 artikel yang masuk ke dalam pembahasan.

\section{Hasil}

Hasil penelusuran 14 artikel menunjukkan bahwa pembelajaran online menyebkan keluhan MSDs pada bagian tubuh mahasiswa.

Tabel 1. Review Artikel

\begin{tabular}{|c|c|c|}
\hline Penulis & Judul & Hasil \\
\hline$[8]$ & $\begin{array}{l}\text { Analisis Postur Kerja Dengan } \\
\text { Laptop Saat School From Home } \\
\text { Menggunakan Quick Exposure } \\
\text { Check (QEC) Dan Computer } \\
\text { Workstation Ergonomic Self- } \\
\text { Assessment }\end{array}$ & $\begin{array}{l}\text { Mahasiswa mengalami tingkat keluhan sakit dan } \\
\text { sangat sakit pada tubuh bagian punggung hingga } \\
\text { pinggang. Yang mendapat tingkat keluhan tinggi } \\
\text { adalah pada bagian leher, bagian bokong dan } \\
\text { pantat. Untuk klasifikasi subjektivitas tingkat } \\
\text { risiko Nordic Body Map (NBM) adalah tingkat } \\
\text { rendah sebanyak } 41 \text { orang, tingkat sedang } 33 \\
\text { orang, tingkat tinggi } 14 \text { orang. Kuesioner Quick } \\
\text { Exposure Check (QEC) diperoleh } 77 \% \text { mahasiswa } \\
\text { dengan action level 3. }\end{array}$ \\
\hline [9] & $\begin{array}{l}\text { Analisis ergonomi pada perkuliahan } \\
\text { daring menggunakan smartphone } \\
\text { selama masa pandemi covid-19: } \\
\text { Studi kasus Mahasiswa Teknik } \\
\text { Industri Universitas Mulawarman }\end{array}$ & $\begin{array}{l}\text { Mayoritas keluhan MSD terjadi pada bahu kiri dan } \\
\text { kanan }(95 \%) \text {, leher bagian atas }(82.14 \%) \text {, dan } \\
\text { punggung }(72.62 \%) \text {. Sebanyak } 86 \% \text { mahasiswa } \\
\text { mengalami visual fatique, dengan mayoritas gejala } \\
\text { sakit kepala }(71.55 \%) \text {, mata sakit }(68 \%) \text {, dan mata } \\
\text { kering }(60.34 \%) \text {. }\end{array}$ \\
\hline [10] & $\begin{array}{l}\text { Gambaran Keluhan Otot Antara } \\
\text { School From Home Dan Work } \\
\text { From Home Dalam Pandemi } \\
\text { Covid-19 }\end{array}$ & $\begin{array}{l}\text { Gambaran nyeri yang dialami mahasiswa sebelum } \\
\text { melakukan SFH diperoleh } 17 \text { mahasiwa kadang- } \\
\text { kadang mengalami nyeri. Sikap mahasiswa dalam } \\
\text { mengadapi atau mengendalikan nyeri yang dialami }\end{array}$ \\
\hline
\end{tabular}




\begin{tabular}{|c|c|c|}
\hline & & $\begin{array}{l}\text { adalah } 5 \text { orang mahasiswa melakukan istirahat, } 19 \\
\text { orang melakukan perenggangan dan } 1 \text { orang } \\
\text { melakukan pijat. Keluhan nyeri otot tertinggi pada } \\
\text { mahasiswa: } 14 \text { orang mahasiswa mengalami } \\
\text { keluhan di leher, } 9 \text { orang mengeluh pada bagian } \\
\text { pinggang dan pantat atas, dan keluhan pada leher } \\
\text { bawah dan bahu kiri sebanyak } 6 \text { orang. }\end{array}$ \\
\hline [11] & $\begin{array}{l}\text { Identifikasi Keluhan Kesehatan } \\
\text { Mahasiswa Selama Perkuliahan } \\
\text { Daring pada Masa Pandemic } \\
\text { Covid19 }\end{array}$ & $\begin{array}{l}\text { Mahasiswa paling banyak merasakan sakit pada } \\
\text { area tangan (bahu, lengan atas, lengan bawah dan } \\
\text { pergelangan tangan) dan batang tubuh (leher, } \\
\text { punggung, pinggul, pinggang dan pantat). Rasa } \\
\text { sakit pada area tangan disebabkan oleh kegiatan } \\
\text { yang berhubungan dengan kegiatan menulis. }\end{array}$ \\
\hline [12] & $\begin{array}{l}\text { Kelelahan Mata dan Keluhan MSDs } \\
\text { Perkuliahan Daring Selama } \\
\text { Pandemi COVID-19 pada } \\
\text { Mahasiswa di Tiga Fakultas } \\
\text { Universitas Sari Mulia (Program } \\
\text { Studi Teknik Industri, D-IV } \\
\text { Promosi Kesehatan dan Program } \\
\text { Studi Manajemen) }\end{array}$ & $\begin{array}{l}\text { Hasil penelitian menunjukkan keluhan MSDs pada } \\
\text { mahasiswa adalah mayoritas pada bagian pinggang } \\
\text { sebanyak } 34 \text { orang }(61,8 \%) \text {, pada bagian leher atas } \\
\text { sebanyak } 33 \text { orang ( } 60 \%) \text { dan pada bagian leher } \\
\text { bawah sebanyak } 25 \text { orang }(45,5 \%) \text {. }\end{array}$ \\
\hline [13] & $\begin{array}{l}\text { Keluhan Muskuloskeletal Akibat } \\
\text { Penggunaan Gawai pada } \\
\text { Mahasiswa Fakultas Kedokteran } \\
\text { Universitas Sam Ratulangi Selama } \\
\text { Pandemi COVID-19 }\end{array}$ & $\begin{array}{l}\text { Responden sebanyak } 183 \text { orang. Keluhan } \\
\text { muskuloskeletal yang sering dirasakan yaitu } \\
\text { keluhan pada leher }(\mathrm{n}=92 ; 50.3 \%) \text {, bahu }(\mathrm{n}=76 \text {; } \\
41.5 \%) \text {, punggung atas }(\mathrm{n}=63 ; 34.4 \%) \text { dan } \\
\text { punggung bawah ( }=63 ; 34.4 \%) \text {. Karakteristik } \\
\text { nyeri yang sering dialami yaitu nyeri ringan. Uji } \\
\text { korelasi Spearman mendapatkan korelasi } \\
\text { bermakna antara: keluhan muskuloskeletal pada } \\
\text { bahu dan lengan dengan durasi pembelajaran; } \\
\text { keluhan muskuloskeletal pada siku dengan durasi } \\
\text { media sosial; serta keluhan muskuloskeletal pada } \\
\text { punggung atas dan punggung bawah dengan durasi } \\
\text { pembelajaran. }\end{array}$ \\
\hline [14] & $\begin{array}{l}\text { Kajian Ergonomi Sarana } \\
\text { Pendukung Proses Belajar } \\
\text { Terhadap Keluhan Gotrak } \\
\text { Mahasiswa Institusi Pendidikan X }\end{array}$ & $\begin{array}{l}\text { Keluhan pada bagian leher yaitu sebesar } 90,48 \% \text {, } \\
\text { kemudian keluhan pada bagian punggung dan } \\
\text { pantat sebesar } 76,19 \% \text {, pinggang } 73,80 \% \text {, bahu } \\
\text { kanan } 50 \% \text {, bahu kiri } 47,62 \% \text {, tangan kiri } 45,24 \% \text {, } \\
\text { kaki kanan } 30,95 \% \text {, tangan kanan } 30,09 \% \text { dan } \\
\text { yang paling sedikit dikeluhkan adalah pada bagian } \\
\text { kaki kiri sebesar } 28,57 \% \text {. }\end{array}$ \\
\hline [15] & $\begin{array}{l}\text { The Correlation between Position } \\
\text { and Duration Use of Laptops with } \\
\text { Musculoskeletal Disorders (MSDs) }\end{array}$ & $\begin{array}{l}\text { Hasil penelitian didapatkan responden } \\
\text { menggunakan laptop dengan durasi tinggi } \\
(48,8 \%) \text {, posisi tidak baik }(42,3 \%) \text {, keluhan } \\
\text { musculoskeletal paling banyak dirasakan pada } \\
\text { daerah leher }(75,5 \%) \text {. Terdapat hubungan posisi } \\
\text { penggunaan laptop dengan keluhan } \\
\text { musculoskeletal dan tidak terdapat hubungan } \\
\text { durasi penggunaan laptop dengan keluhan } \\
\text { musculoskeletal. }\end{array}$ \\
\hline [16] & $\begin{array}{l}\text { COVID-19 pandemic and } \\
\text { lockdown: cause of sleep } \\
\text { disruption, depression, somatic } \\
\text { pain, and increased screen exposure } \\
\text { of office workers and students of } \\
\text { India }\end{array}$ & $\begin{array}{l}\text { Ketidaknyamanan bagian tubuh pada mahasiswa } \\
\text { sebelum dan selama pandemi adalah di leher, bahu, } \\
\text { siku, pergelangan tangan, punggung, bawah } \\
\text { punggung, pinggul, lutut, dan pergelangan kaki. }\end{array}$ \\
\hline [17] & $\begin{array}{l}\text { Musculoskeletal Pain and Non- } \\
\text { Classroom Teaching in Times of } \\
\text { the COVID-19 Pandemic: Analysis } \\
\text { of the Impact on Students from } \\
\text { Two Spanish Universities }\end{array}$ & $\begin{array}{l}\text { Peningkatan keluhan MSDs pada bagian tubuh dari } \\
\text { sebelum pandemi dan pada saat pandemic adalah } \\
\text { leher, punggung, dan pinggang. }\end{array}$ \\
\hline
\end{tabular}




\begin{tabular}{|c|c|c|}
\hline [18] & $\begin{array}{l}\text { Musculoskeletal Pain in Medical } \\
\text { Students Subject to Remote } \\
\text { Teaching during the COVID-19 } \\
\text { Pandemic }\end{array}$ & $\begin{array}{l}\text { Sebelum pembelajaran jarak jauh, } 98 \text { orang } \\
\text { mahasiswa tidak mengalami keluhan MSDs. } \\
\text { Setelah pandemic, } 103 \text { orang mahasiswa } \\
\text { mengalami keluhan MSDs. Sebelum pandemi, } \\
\text { keluhan MSDs berada di bagian tubuh tulang } \\
\text { belakang lumbar, leher tulang belakang, otot } \\
\text { trapezius, bahu, lutut, pinggul, tungkai bawah dan } \\
\text { atas, dan bagian tubuh yang terkait dengan } \\
\text { aktivitas fisik. }\end{array}$ \\
\hline [19] & $\begin{array}{l}\text { Risk Assessment during Covid-19 } \\
\text { and Learning from Home: Evidence } \\
\text { from University Students in } \\
\text { Indonesia }\end{array}$ & $\begin{array}{l}\text { Keluhan MSDs pada mahasiswa adalah di bagian } \\
\text { leher, bahu, siku, punggung atas, punggung bawah, } \\
\text { panggul dan lutut. }\end{array}$ \\
\hline [20] & $\begin{array}{l}\text { The psychophysiological effects of } \\
\text { the COVID-19 quarantine in } \\
\text { the college students }\end{array}$ & $\begin{array}{l}\text { Aktivitas fisik yang rendah, kualitas tidur dan } \\
\text { tingginya keluhan MSDs berhubungan dengan } \\
\text { kualitas tidur yang rendah, dan suasana hati yang } \\
\text { negatif. Untuk bagian tubuh responden yang } \\
\text { mengalami rasa sakit adalah leher, bahu, punggung } \\
\text { atas dan bawah. }\end{array}$ \\
\hline [21] & $\begin{array}{l}\text { The Impact of E-learning During } \\
\text { COVID-19 Pandemic on Body } \\
\text { Aches among Students in a } \\
\text { Palestinian University }\end{array}$ & $\begin{array}{l}\text { Hasil penelitian menunjukkan bahwa } 48,3 \% \\
\text { responden merasa sakit pada bagian leher, } \\
\text { punggung dan bahu, dan akan bertambah sesudah } \\
\text { pembelajaran online. Sebanyak } 8,6 \% \text { responden } \\
\text { menyatakan bahwa rasa sakit pada bagian leher, } \\
\text { punggung dan bahu tidak bertambah pada saat } \\
\text { pembelajaran online telah selesai. } 43,2 \% \\
\text { responden menyatakan bahwa tidak memiliki } \\
\text { riwayat sakit pada leher, punggung dan bahu. Pada } \\
\text { pertanyaan seputar rasa sakit, hasil penelitian } \\
\text { menunjukkan } 32,2 \% \text { merasakan sakit bagian leher, } \\
15,3 \% \text { pada bagian bahu kanan, } 20 \% \text { pada bagian } \\
\text { bahu kiri, } 15,1 \% \text { bagian punggung dan } 17,4 \% \text { tidak } \\
\text { merasakan sakit sama sekali. Hasil penelitian juga } \\
\text { menunjukkan bahwa ada hubungan antara } \\
\text { penggunaan laptop/tablet dengan rasa sakit yang } \\
\text { timbul di bagian tubuh }\end{array}$ \\
\hline
\end{tabular}

\section{Pembahasan}

Mewabahnya Virus Covid-19 ke semua negara yang mengakibatkan banyak korban jiwa yang meninggal dunia berdampak terhadap semua sektor. Salah satu sektor tersebut adalah pendidikan. Institusi pendidikan menerapkan kebijakan sistem pembelajaran online dalam rangka mencegah penyebaran Virus Covid-19. Penyebaran virus Corona dapat terjadi melalui kontak antara satu individu dengan individu lainnya (melalui sentuhan, air liur, dll) sehingga perlu untuk melakukan social distancing dan bahkan physical distancing untuk menghambat penyebaran COVID-19 [8]. Pelaksanaan pembelajaran online dilakukan dengan memanfaatkan teknologi informasi melalui perangkat handphone, komputer atau laptop yang saling terhubung antara mahasiswa dan dosen. Saat ini, mayoritas mahasiswa memilih laptop dalam menunjang proses pembelajaran seperti mengikuti perkuliahan dan mengerjakan tugas maupun untuk akses internet karena sifatnya lebih fleksibel dan fashionable Aktivitas di depan laptop seringkali dilakukan dalam postur yang tidak ergonomis dan dilakukan secara berulang sehingga dapat berpotensi menyebakan kelelahan dan gangguan kesehatan seperti keluhan musculoskeletal [22]. Berdasarkan artikel yang telah di review, menunjukkan bahwa pembelajaran online berdampak pada kesehatan mahasiswa. Keluhan kesehatan pada mahasiswa mayoritas pada bagian leher, bahu, punggung, dan pinggang. Hasil penelitian oleh Herman et al, menyatakan mayoritas responden menggunakan laptop dengan posisi duduk yang tidak direkomendasikan. Selain itu, siswa di rumah yang mengikuti perkuliahan online memiliki keterbatasan prasarana pembelajaran yang mendukung sesuai dengan kaidah ergonomi. Sebagai tambahan, budaya di Indonesia yang mayoritas lebih senang untuk duduk di lantai dan juga sama seperti halnya menonton TV sambil berbaring turut mempengaruhi kebiasaan dalam mengikuti perkuliahan online [23]. 
Fakta bahwa tingginya pelaporan terkait dengan keluhan musculoskeletal pada leher, bahu dan punggung tidaklah mengejutkan mengingat posisi tubuh mengikuti perkuliahan online di rumah tidak mengikuti kaidah ergonomi. Penggunaan laptop di meja tanpa posisi tubuh yang direkomendasikan mengakibatkan keluhan musculoskeletal pada leher dan bahu. Berbaring pada tempat tidur yang mengharuskan responden untuk bersandar pada bagian leher dan tumpuan berat badan pada siku menyebabkan terjadinya peningkatan keluhan musculoskeletal pada bagian leher dan punggung. Hasil pelaporan ini harus ditindaklanjuti karena prevalensi yang berkepanjangan keluhan musculoskeletal pada bagian leher dan punggung tidak hanya akan menyebabkan gangguan rasa sakit tetapi juga dapat menyebabkan absen kerja, gangguan tidur dan kecacatan [23]. Hasil penelitian oleh Joseph menyatakan bahwa pembatasan sosial dan kurangnya aktivitas di luar ruangan mempengaruhi nyeri pada bagian tubuh [24]. Pernyataan ini didukung oleh hasil penelitian pada mahasiswa di dua Universitas Spanyol bahwa kurangnya aktivitas fisik meningkatkan resiko keluhan musculoskeletal.

\section{Kesimpulan}

Kebijakan pelaksanaan pembelajaran online yang diterapkan dalam rangka mencegah penyebaran Virus Covid-19 berdampak pada aspek kesehatan. Tidak bisa dipungkiri, dengan adanya kebijakan pengurangan aktivitas sosial dan di luar ruangan memberi pengaruh terhadap keluhan musculoskeletal. Mahasiswa sebagai responden penelitian ini, juga mengalami keluhan musculoskeletal pada berbagai bagian tubuh. Apabila keluhan musculoskeletal ini diabaikan, maka akan berdampak buruk pada absen, gangguan tidur dan kecacatan.

\section{Daftar Pustaka}

[1] World Health Organization. "Director-General's Opening Remarks at the Media Briefing On COVID-19,"11 March 2020. [Online] Available: https://www.who.int/directorgeneral/speeches/detail/who-director-general-s-opening-remarks-at-the-media-briefing-oncovid-19---11-march-2020. [Acessed: 15 Oktober 2021].

[2] WHO Coronavirus (COVID-19) Dashboard. [Online] Available: https://covid19.who.int/. [Acessed: 20 Oktober 2021].

[3] Peta sebaran Covid-19 di Indonesia. [Online] Available: https://covid19.go.id/peta-sebaran. [Acessed: 20 Oktober 2021].

[4] A. D. Minghat, A. Ana, P. Purnawarman, S. Saripudin, M. Muktiarni, V. Dwiyanti, and S.S. Mustakim, "Students Perceptions of the Twists and Turns of E-learning in the Midst of the Covid 19 Outbreak," Revista Romaneasca pentru Educatie Multidimensionala, vol.12, no. 5, pp. 15-26, 2020.

[5] H. Sengul, A. Bulut, M. A. Adalan, "Investigation of The Change of Lockdowns Applied Due To COVID-19 Pandemic on Musculoskeletal Discomfort," International Journal of Human Sciences, vol. 17, no.4, pp. 974-985, 2020.

[6] A. P. Thirion, E. F. Macías, J. Hurley, G. Vermeylen, "Fourth European Working Conditions Survey," European Foundation for the Improvement of Living and Working Conditions Report. [Online] Available: eurofound.euro.eu/publications/report/2007/working-conditions/fourtheuropean-working-conditions-survey. [Acessed: 20 Oktober 2021].

[7] Y. Kim, H. T. Chen, and Y. Wang, "Living in the Smartphone Age: Examining the Conditional Indirect Effects of Mobile Phone Use on Political Participation," Journal of Broadcasting \& Electronic Media, vol. 60, no. 4, pp. 694-713, 2016. doi: 10.1080/08838151.2016.1203318.

[8] I. Ferlinda and E. Muslimah, Analisis Postur Kerja Dengan Laptop Saat School from Home Menggunakan Quick Exposure Check (QEC) Dan Computer Workstation Ergonomic SelfAssessmen, Skripsi, Jurusan Teknik Industri. Jawa Tengah: Universitas Muhammadiyah Surakarta, 2021.

[9] L. D. Fathimahhayati, T. A. Pawitra, and W. Tambunan, "Analisis ergonomi pada perkuliahan daring menggunakan smartphone selama masa pandemi covid-19: Studi kasus Mahasiswa Teknik Industri Universitas Mulawarman," Journal of Applied Industrial Engineering, vol. 12, no. 3, pp. 308- 317, 2020. doi: 10.22441/oe.2020.v12.i3.004.

[10] B. Yoni, S. Nugroho, E. Widianawati, and W. R. Wulan, "Gambaran Keluhan Otot Antara School From Home Dan Work From Home Dalam Pandemi Covid-19," Jurnal Kesehatan Masyarakat Visikes, vol. 19, no. 2, pp. 514-521, 2020. doi: 10.33633/visikes.v19i2.4030 
[11] M. Sobirin, "Identifikasi Keluhan Kesehatan Mahasiswa Selama Perkuliahan Daring pada Masa Pandemic Covid 19," Performa: Media Ilmiah Teknik Industri, vol. 19, no. 1, pp. 49-54, 2020. doi: 10.33633/visikes.v19i2.4030

[12] M. S. M. O. S. S. Tambun and H. Oktavianoor, "Kelelahan Mata dan Keluhan MSDs Perkuliahan Daring Selama Pandemi COVID-19 pada Mahasiswa di Tiga Fakultas Universitas Sari Mulia (Program Studi Teknik Industri, D-IV Promosi Kesehatan dan Manajemen)," Jurnal Media Teknik dan Sistem Industri, vol.5, no.2, pp. 92-101, 2021.

[13] G. O. Batara, D. V. D. Doda, and H. I. S. Wungouw, "Keluhan Muskuloskeletal Akibat Penggunaan Gawai pada Mahasiswa Fakultas Kedokteran Universitas Sam Ratulangi Selama Pandemi COVID-19," Jurnal Biomedik, vol. 13, no. 2, pp. 152-160, 2021, doi: 10.35790/jbm.13.2.2021.31767

[14] V. F. Aryadi and I. H. Susilowati, "Kajian Ergonomi Sarana Pendukung Proses Belajar Terhadap Keluhan Gotrak Mahasiswa Institusi Pendidikan X," Prepotif Jurnal Kesehatan Masyarakat, vol. 5 , no. 2 , pp. $742-748,2021$

[15] R. A. Tanzila, T. Prameswarie, M. D. Hartanti, and T. Denaneer, "The Correlation between Position and Duration Use of Laptops with Musculoskeletal Disorders (MSDs)," Mutiara Medika Jurnal Kedokteran dan Kesehatan, vol. 21, no. 2, pp. 79-85.

[16] P. Majumdar, A. Biswas, and S. Sahu, "COVID-19 pandemic and lockdown: cause of sleep disruption, depression, somatic pain, and increased screen exposure of office workers and students of India," Journal of Biological and Medical Rhythm Research, vol. 37, no. 8, pp. 1191-1200, 2020.

[17] R. L. Rodríguez, Ó. R. Nogueira, A. P. Carral, M. J. Á. Álvarez, M. Á. G. Martín, F. M. Cuadrado, and J. A. B. Andrades, "Musculoskeletal Pain and Non-Classroom Teaching in Times of the COVID-19 Pandemic: Analysis of the Impact on Students from Two Spanish Universities," Journal of Clinical Medicine, vol. 9, no. 12, 2020.

[18] I. d. P. Gomes, V. Mitleton, L. G. B. Fiorin, C. d. S. Leite, and O. C. Pires, "Musculoskeletal Pain in Medical Students Subject to Remote Teaching during the COVID-19 Pandemic," Journal of Biosciences and Medicines, vol. 9, no. 8, pp. 92-99, 2021. doi: 10.4236/jbm.2021.98008.

[19] H. R. Soetisna, A. Widyanti, A. Syafira, D. A. Pujiartati, "Risk Assessment during Covid-19 and Learning from Home: Evidence from University Students in Indonesia," Journal Optimasi Sistem Industri, vol. 20, no.1, pp. 42-51, 2021. doi: 10.25077/josi.v20.n1.p42-51.2021

[20] Y, Soylu, "The Psychophysiological Effects of the COVID-19 Quarantine in the College Students," Physical Education of Student, vol. 25, no. 3, pp. 158-163, 2021. doi:10.15561/20755279.2021.0303

[21] Q. B. Yaseen, H. Salah, "The Impact of E-learning During COVID-19 Pandemic on Body Aches among Students in a Palestinian University," Research Square, pp. 1-18, 2021. doi: 10.21203/rs.3.rs-778931/v1

[22] I. M. K. Dinata, N. Adiputra, I. P. G. Adiatmika, "Sikap Kerja Duduk-Berdiri Bergantian Menurunkan Kelelahan, Keluhan Muskuloskeletal Serta Meningkatkan Produktivitas Kerja Penyetrika Wanita di Rumah Tangga," Jurnal Ergonomi Indonesia (The Indonesian Journal of Ergonomic), vol. 1, no.1, pp. 30-40, 2015. doi: 10.24843/JEI.2015.v01.i01.p04

[23] J. B. Hurlbut, "A Science that Knows No Country: Pandemic Preparedness, Global Risk, Sovereign Science,” Sage Journals, pp. 1-14, 2017. doi: 10.1177/2053951717742417

[24] S. J. Joseph, S. Sg. T. Shoib, and S. S. Bhandari, "Psychological Concerns and Musculoskeletal Pain Amidst The COVID-19 Lockdown", Open Journal of Psychiatry Allied Sciences, vol. 11, no. 2, pp. 137-139, 2020. doi: 10.5958/2394-2061.2020.00026.9. 